\title{
The development, educational stratification and decomposition of mothers' and fathers' childcare time in Germany. An update for 2001-2013
}

\author{
Die Entwicklung, die Bildungsstratifizierung und die Dekomposition der \\ Zeitverwendung für Kinderbetreuung von Müttern und Vätern in \\ Deutschland. Eine Aktualisierung für die Jahre 2001-2013
}

\begin{abstract}
:
This study updates empirical knowledge about (1) the development, (2) the educational stratification, and (3) the decomposition of mothers' and fathers' childcare time in Germany with the most recent time use data. Using time series data from the German Time Use Study 2001/2002 and 2012/ 2013, we analyze time budgets for total childcare and six specific childcare activities on weekdays and weekends and estimate OLS regressions and Oaxaca decompositions. The study found that (1) total childcare time has increased for mothers and fathers between 2001 and 2013 and that this change is predominantly due to increased time for basic childcare. (2) It also found consistent evidence of an education gradient only for reading time with children. (3) If there is significant change of time budgets between 2001 and 2013, this change seems to be driven by behavioral change rather than changing demographics. Our empirical findings on childcare time in Germany do not provide evidence of dynamics and stratification but rather of stability and similarity across parents' educational levels. Besides the updates on German parents' development, stratification and decomposition of time use for childcare, these analyses show that change in total childcare is not due to a proportional change over all single activities but due to changes in a few activities only.
\end{abstract}

Key words: time, childcare, Germamy, mothers, fathers

\section{Zusammenfassung:}

Diese Studie aktualisiert das empirische Wissen über die Entwicklung, die Bildungsstratifizierung und die Dekomposition der Zeitverwendung von Müttern und Vätern für Kinderbetreuung mit den aktuellen Zeitbudgetdaten für Deutschland. Auf Basis der der letzten beiden Erhebungen der Deutschen Zeitverwendungsstudie 2001/2002 und 2012/2013 werden die Zeitbudgets für die Gesamtzeit für Kinderbetreuung sowie sechs Einzeltätigkeiten mit OLS-Regressionen und OaxacaDekompositionen untersucht. Die Studie zeigt, dass (1) die Zeit für Kinderbetreuung von Müttern und Vätern zwischen 2001 und 2013 angestiegen ist, (2) es einen Bildungsgradienten für Vorlesen gibt und (3) signifikante Veränderungen in den Zeitbudgets nicht auf Kompositionsveränderung der Bevölkerung zurückgeführt werden können. Insgesamt belegt die Studie weniger die Dynamik als vielmehr die Stabilität und die geringe Bildungsdifferenzierung der Zeitverwendung für Kinderbetreuung. Darüber hinaus wird gezeigt, dass die Veränderungen in der Gesamtzeit für Kinderbetreuung nicht auf proportionale Veränderungen in allen, sondern nur auf Veränderungen in wenigen Einzeltätigkeiten zurückgeführt werden können.

Schlagwörter: Zeitverwendung, Kinderbetreuung, Deutschland, Mütter, Väter 


\section{Introduction}

In Germany, the role of the family as a learning environment and the parents' contribution and support for the development of their children are traditionally of high socio-political importance. In this context, several recent international studies have highlighted that the time mothers and fathers spend on childcare is beneficial for the development and wellbeing of their children (e.g., Altintas 2016; Bonke/Esping-Andersen 2011; Hallberg/Klevmarken 2003; Kalil/Ryan/Corey 2012; Sayer/Gauthier/Furstenberg 2004; Dotti Sani/Treas 2016). There is early evidence in the literature that parents' time with children, shared parent-child activities and parental interaction with their children are positively linked to children's outcomes in later life (already, e.g., Leibowitz 1974, 1977). Further, there is ample evidence that parents' time for childcare is highly stratified: highly educated mothers and fathers tend to spend more time on childcare - and particularly developmental childcare - than lower educated parents (e.g., Altintas 2016; Dotti Sani/Treas 2016; Kalil/Ryan/Corey 2012; Sayer/Gauthier/Furstenberg 2004). This different investment behavior in children aroused a discussion about 'diverging destinies', that is, an increasing inequality with "important implications for long-term patterns of attainment and achievement" between children of higher versus lower educated parents (Kalil/Ryan/Corey 2012: 1362; McLanahan 2004).

However, to date, there is little and somewhat outdated evidence on these issues for Germany. The most recent time-use studies covering Germany (Berghammer 2013; Dotti Sani and Treas 2016) only cover periods until the early 2000s and, thus, the subsequent period until 2012/2013 is, as yet, unexplored. Besides official statistics (Statistisches Bundesamt 2015, 2017), there is no single 'case study' of parental time investments in their children in Germany. Germany has only been part of a few internationally comparative time use analyses (e.g., Berghammer 2013; Gauthier/Smeeding/Furstenberg 2004; Dotti Sani/Treas 2016). These previous analyses have focused more on general trends of aggregated time budgets and have not considered developments for more specific childcare activities. Yet, as studies have shown, analyzing the composition of total time for childcare and its development yields additional evidence of parental behavior regarding the interaction with their children (Craig/ Powell/Smyth 2014).

In light of this, we contribute to the literature on parental childcare time in a number of ways. First, we provide an update of previous work in Germany. This is done by analyzing the developments in women's and men's childcare time over the most recent ten years using data from the 2001/2002 and 2012/2013 German Time Use Study. Second, we analyze trends for six specific childcare activities, subdividing total parental time use to a greater extent than before in the literature. Third, we provide evidence of the education gradient of total and specific childcare time in Germany over this decade in order to update knowledge on the social stratification of time use. Fourth, we do a decomposition analysis of time use developments between 2001/2002 and 2012/2013. The aim here is to assess the relative contribution of changing demographic distributions versus changes that are statistically independent from population parameters on childcare time, again primarily focusing on mothers' and fathers' education. 


\section{Background}

In order to embed this study in the literature on changing time use for childcare, we review relevant research about the trends and explanations of development, stratification and decomposition of childcare time, describe previous evidence for Germany for each of these issues and add expectations derived from this background as guidance for our own empirical analyses. As research on parental childcare time has drawn on basically the same background literature over the years, the framework will be brief and reduced to the most important points which have proven to be shared by most of the other researchers in this field (e.g., Altintas 2016; Dotti Sani/Treas 2016; England/Srivastava 2013; Kalil/ Ryan/Corey 2012; Sayer/ Bianchi/Robinson 2004; Sayer/Gauthier/Furstenberg 2004).

\section{Development of childcare time}

There is wide agreement in the literature that parental childcare time in western societies has increased over the last decades and that women spend more time with their children than men. This is the case despite an increase in adults' obligations in other spheres of life, especially the growth of women's participation in the labor market (e.g., Dotti Sani/Treas 2016; Gauthier/Smeeding/Furstenberg 2004; Sayer/Bianchi/Robinson 2004). This increase is commonly framed within the notion of changing ideas about parenting (as reviewed in, e.g., Altintas 2016; Dotti Sani/Treas 2016). Throughout western societies, patterns of parental involvement in children's cognitive, educational and social development have emerged over recent years. Mothers and fathers are becoming more and more aware that 'modern child rearing' requires active investment in developmentally enriching activities and, thus, quality time with their children. As Altintas (2016) outlines in a historical overview, approval and adoption of these new practices, labeled 'intensive mothering' (Hays) or 'new fatherhood', in everyday lives have increased over the last century. Concurrently, public discussion on child rearing and the positive effects of active parental involvement has triggered parents to in-crease their engagement in childcare. Taken together, "the idea that parents must contribute to their children's cognitive and social development by means of substantial time and financial investments" (Altintas 2016: 28) is interrelated with increasing childcare time, both processes mutually reinforcing each other.

For Germany, using data of the Multinational Time Use Study (MTUS), Gauthier, Smeeding, and Furstenberg (2004) reported that total time for childcare of mothers and fathers increased between the mid-1960s and the early 1990s. Berghammer (2013), using data of the German Time Use Survey from 1991/1992 and 2001/2002, and Dotti Sani and Treas (2016), using data of the MTUS, found that time budgets were rather stable in the subsequent decade until the early 2000s. All studies for Germany agreed that mothers spend more time on childcare than fathers do and that this gender gradient has been relatively stable over the years, although fathers contribution to childcare has slightly increased (Berghammer 2013; Dotti Sani/Treas 2016; Gauthier/Smeeding/Furstenberg 2004; Guryan/Hurst/Krearney 2008; Sayer/Gauthier/Furstenberg 2004).

In our empirical study, we expect to find increasing or at least stable time budgets for childcare in Germany between 2001 and 2013. Given the intense public debate on child 
development and early education of children in Germany in recent years, we at least expect to find an increase of time for developmental activities such as reading.

\section{Stratification of childcare time: The education gradient}

According to economic (human capital) theory, parents invest time and money to support the development of their children. The allocation of time, meanwhile, is decided on the basis of efficiency and opportunity costs. Given the increase of maternal, and the stability of paternal, employment over recent decades, this mechanism should have reduced time for childcare as it can be interpreted as not equally economically productive as spending time in paid labor. However, most time-use studies of childcare find exactly the opposite of the predictions of economic reasoning. That is to say, highly educated mothers and fathers spend more time for childcare, and especially in developmentally enriching activities (e.g., Altintas 2015, 2016; Bianchi/Robinson 1997; Craig/Powell/Smyth 2014; England/Srivastava 2013; Sayer/Gauthier/Furstenberg 2004). Kalil/Ryan/Corey (2012) further reported that highly educated parents tend to adjust their childcare activities with regard to the age-dependent developmental needs of their children.

Findings like these are in line with a 'cultural explanation' of the education gradient drawing on class-differential patterns of parenting (England/Srivastava 2013). In her study of 'unequal childhoods', Lareau (2011) suggests that parents with less education tend to view child development as "natural growth". Thus, they try to address the basic needs of children in terms of emotional and material support but presume that skills and talents develop rather naturally without much parental intervention (Kalil/Ryan/Corey 2012: 1364). Highly educated parents, on the other hand, engage much more in their children's lives in order to actively support their skill development early on - a pattern called "concerted cultivation". Clearly, this perspective predicts a positive education gradient for mothers and fathers (England/Srivastava 2013). Additionally, highly educated parents should have better economic, social and normative resources to put the new ideologies of parenting, described above, into practice.

For Germany, Sayer, Gauthier, and Furstenberg (2004) and Guryan, Hurst, and Kearney (2008), both using data of the German Time Use Survey from 1991/1992, provided cross-sectional evidence of a positive education gradient in childcare time for women and men from the early 1990s: higher educated parents devoted significantly more time to childcare than did lower educated ones. Dotti Sani and Treas (2016), however, did not replicate this finding for 1992/1993 and 2001/2002; neither did Berghammer (2013).

In our empirical study, we not only provide updated evidence for the education gradient of total childcare time for the most recent decade in Germany, but also add evidence of the direction and significance on an education gradient for specific childcare activities.

\section{Population composition and childcare time}

Research has documented several compositional factors that are associated with childcare time (Berghammer 2013; Sandberg/Hofferth 2001; Sayer/Bianchi/Robinson 2004), for example, increased single parenting, declining family size, increased maternal employ- 
ment, as well as educational expansion, especially for women. Regarding education - the main focus of our analysis - Sayer, Bianchi, and Robinson (2004: 7) argue that increasing average educational levels over time, together with the assumption of a positive education gradient, should produce an increase in mothers' and fathers' average time for childcare. For the US, Sayer, Bianchi, and Robinson (2004: 29-30) reported that 'negative' compositional changes for married mothers were compensated by 'positive' behavioral changes to account for an overall increase of mothers' time budgets for childcare. For married fathers, the relative contribution of behavioral change for the observed increasing childcare time is about 90 percent, with shifts in paternal education accounting for most of the remaining ten percent of compositional change. Sandberg and Hofferth conclude from their analysis of children's time with parents that "behavioral changes generally outweighed the effects of changes in demographics" (2001: 434).

For Germany, Berghammer (2013) has provided the only evidence so far on this issue. In her analysis of the German Time Use Survey between 1991/1992 and 2001/2002, she found that compositional shifts contribute only marginally, and, if so, negatively on parental time use for total childcare. However, as relatively perpetual time budgets in her observation period suggest, behavioral changes also have only marginal influence on parental childcare time.

In our empirical study, we examine, first, if Berghammer's (2013) 'null result' for total childcare time still holds for Germany, and, second, which patterns can be detected for single activities.

\section{Data and method}

\section{Data}

We used time series data of the two recent surveys of the German Time Use Study (GTUS), which were conducted as nationally representative household samples in 2001/2002 and 2012/2013 by the German Federal Statistical Office. These two repeated cross-sectional surveys portray the whole German population for all days of the week and for all months of the year, collecting data with the time diary approach. Using time diaries is regarded as superior in capturing time use patterns compared to other methods, such as stylized survey questions on time use (Kan/Pudney 2008). In particular, childcare time is captured in much greater detail in diary studies compared to typical population surveys and is claimed to be less prone to over-reporting and social desirability bias (e.g., Altintas 2016; Hofferth 2006).

The 2001/2002 and 2012/2013 GTUS were the second and third surveys of its kind, succeeding the first time budget survey of 1991/1992. In both surveys, a representative sample of more than 5000 German households was surveyed about their everyday behavior. Each household member aged 10 years or older kept a diary for three days (typically two weekdays and one weekend day) and recorded all activities in his or her own words using pre-given intervals of ten minutes each. The activities were subsequently coded according to the 2008 Guidelines for Harmonized European Time Use Surveys (Ehling/ Holz/Kahle 2001; Maier 2014). 


\section{Sample selection}

We analyzed the time use for childcare activities of all parents in both surveys with at least one child aged 13 years or younger in the household, to be comparable with the most recent study by Dotti Sani and Treas (2016). We restricted the sample to one- or twoparent households; that is, no other persons lived in these family households. This was done to ensure that parental time budgets could not be obviously affected by third persons. We used all diaries of the selected mothers and fathers, those from weekdays (Mondays to Fridays) as well as weekend days (Saturdays and Sundays). Kalil, Ryan, and Corey (2012) argue that, on weekends, parents might be more flexible in devoting time to their children, which increases the opportunities for intensive childcare and quality time for children. On weekdays, in turn, the available time budget for childcare is more restricted and, thus, represents more of an 'active choice' between competing activities such as leisure or recreation.

Eventually, we analyzed the time use of 2793 mothers and 2284 fathers, who recorded 5394 and 4401 diaries on weekdays and 2980 and 2442 diaries on weekends, respectively. Table A-1 summarizes the sample characteristics.

\section{Outcome variables: Childcare activities}

We analyzed trends in seven time-use variables: (1) overall time use for children, as all other previous studies for Germany did (Berghammer 2013; Dotti Sani/Treas 2016; Gauthier/Smeeding/Furstenberg 2004), and six more specific childcare activities within the overall time budget for children. These were as follows: (2) basic childcare, such as feeding, changing diapers, or daily hygiene; (3) helping, teaching and learning activities with children; (4) playing with children; (5) talking with children; (6) managerial activities for children; and (7) reading to and with children and telling them stories. Due to harmonization problems on the level of single activities, we did not use data from the first survey of the GTUS from 1991/1992; incidentally, the period between 1991 and 2002 has already been studied extensively by other researchers (Berghammer 2013; Dotti Sani/Treas 2016). We focused on primary activities only. This was because, first, developmental care, in particular, requires much more and direct attention to the child than that which is captured with secondary childcare time or time of co-presence with children. Second, main activities are presumably more efficient in capturing comparable time budgets in different surveys (Kitterød 2001). Table A-2 reports means and participation rates of the seven time budgets for childcare in our data.

\section{Explanatory variables and controls}

The main explanatory variables were mothers' and fathers' educational levels. We differentiated between women and men with (resembling ISCED $5+6$ or CASMIN $3 a+3 b$ ) or without university qualifications, as higher education is associated with higher material and mental resources as well as specific awareness of issues of child development (e.g., Dotti Sani/Treas 2016; England/Srivastava 2013). 
We estimated separate models for mothers' and fathers' time use on weekdays and weekends throughout our analyses and further differentiated between the two survey years. In our regression models, we controlled for common demographics in analyses of childcare time (e.g., Altintas 2016; Kalil/Ryan/Corey 2012; Dotti Sani/Treas 2016; Monna/Gauthier 2008): age of respondents, partnership status, number of children in the household, and age of youngest child. Including various variables for labor market participation did not change the results.

\section{Analytical strategy}

First, applying OLS models, we regressed each of our seven time budgets on our main explanatory variable - educational level - controlling for other possible predictors, using cluster robust standard errors to account for up to two diaries per respondent. Based on the OLS models (Tables A-3, A-4), we estimated the margins at the means (Williams 2012) to draw the picture of development of childcare time for Germany, adjusting the time budgets by setting all covariates to the sample means (Figures 1,2). Applying OLS regression is common in time-use research, and recent methodological studies justified the use of these models over other possible alternatives (Foster/Kalenkoski 2013; Stewart 2009). The conclusions from our OLS models proved to be robust compared to other modeling approaches.

Second, the b-coefficients and standard errors for the variable 'university degree' of each equation of the seven OLS models (Tables A-3, A-4) gave us information about the direction and the significance of education gradient of childcare time. This is because they can be interpreted as average marginal effects of education in the linear case (graphically displayed in Figures 3, 4).

Third, we analyzed if changes in the education distribution of the population had an effect on trends of mean childcare time in Germany (Table 1). Therefore, we applied a standard two-way decomposition technique (Powers/Hoshioka/Yun 2011). After estimating the dependent variable $Y$ as a function of a linear combination of predictors and regression coefficients, the mean difference in $Y$ between two time points is decomposed as follows:

$$
\begin{gathered}
\bar{Y}_{t 2}-\bar{Y}_{t 1}=F\left(X_{t 2} \beta_{t 2}\right)-F\left(X_{t 1} \beta_{t 1}\right) \\
=\left\{F\left(X_{t 2} \beta_{t 2}\right)-F\left(X_{t 1} \beta_{t 2}\right)\right\}+\left\{F\left(X_{t 1} \beta_{t 2}\right)-F\left(X_{t 1} \beta_{t 1}\right)\right\}=E+C
\end{gathered}
$$

(Powers/Hoshioka/Yun 2011: 558). The first part of the decomposition $E$ refers to the part of the differential attributable to differences in endowments or characteristics. The second part $C$ refers to the part of the differential attributable to differences in coefficients. Usually, $E$ is called the "explained component" and $C$ is called the "unexplained component". A similar decomposition method is applied in childcare time-use research by Sayer, Bianchi, and Robinson (2004); although they did not run significance tests. Berghammer (2013) further estimated the $E C$ interaction as a third component. This information does not add to our research question, however. 


\section{Results}

\section{Development of childcare time in Germany, 2001-2013}

Figures 1 and 2 report mothers' and fathers' predicted childcare minutes per weekday (Mondays through Fridays) and per weekend day (Saturdays or Sundays) for the two survey years of 2001/2002 and 2012/2013.

Figure 1: Development of mothers' time use for total childcare and for specific activities, adjusted average minutes on weekdays and weekends
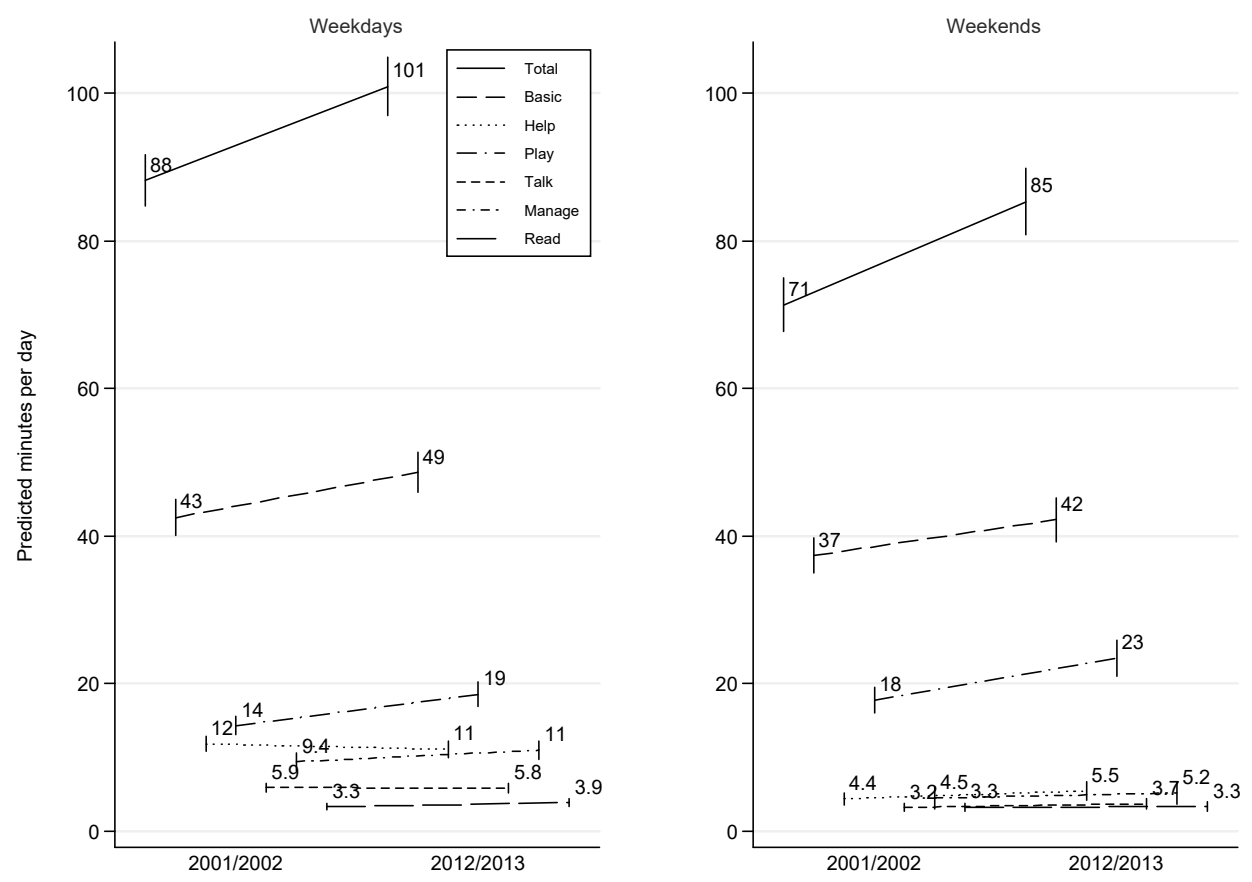

Note. Predictions and 95\%-confidence intervals are calculated as margins at the means from the regression models in Table A2. Source: GTUS 2001/2002, 2012/2013, own calculations. A colorized and resizable figure is available in the supplement to this article at http://dx.doi.org/10.20378/irbo50338.

For mothers (Figure 1), total time for childcare on weekdays has significantly increased over the most recent decade from 88 to 101 minutes per day. Time for basic childcare and playing with children has also increased by about ten minutes, making up for almost the whole change of total childcare time. All other time budgets - for helping, talking, managing and reading - have remained rather stable over our observation period, showing no significant changes for the predicted minutes per day. 
On weekends, mothers' time for total childcare has increased significantly by about 14 minutes, so did time for playing with children by about 5 minutes. There are no significant changes for the other predicted time budgets.

For fathers (Figure 2), the picture for weekdays and weekend days is very similar. Total time for childcare on weekdays has increased significantly by an average of eight minutes per day, from 33 to 41 minutes. This was primarily caused by a significant change of basic childcare time by five minutes and only marginal and non-significant shifts in all the other activities.

Figure 2: Development of fathers' time use for total childcare and for specific activities, adjusted average minutes on weekdays and weekends
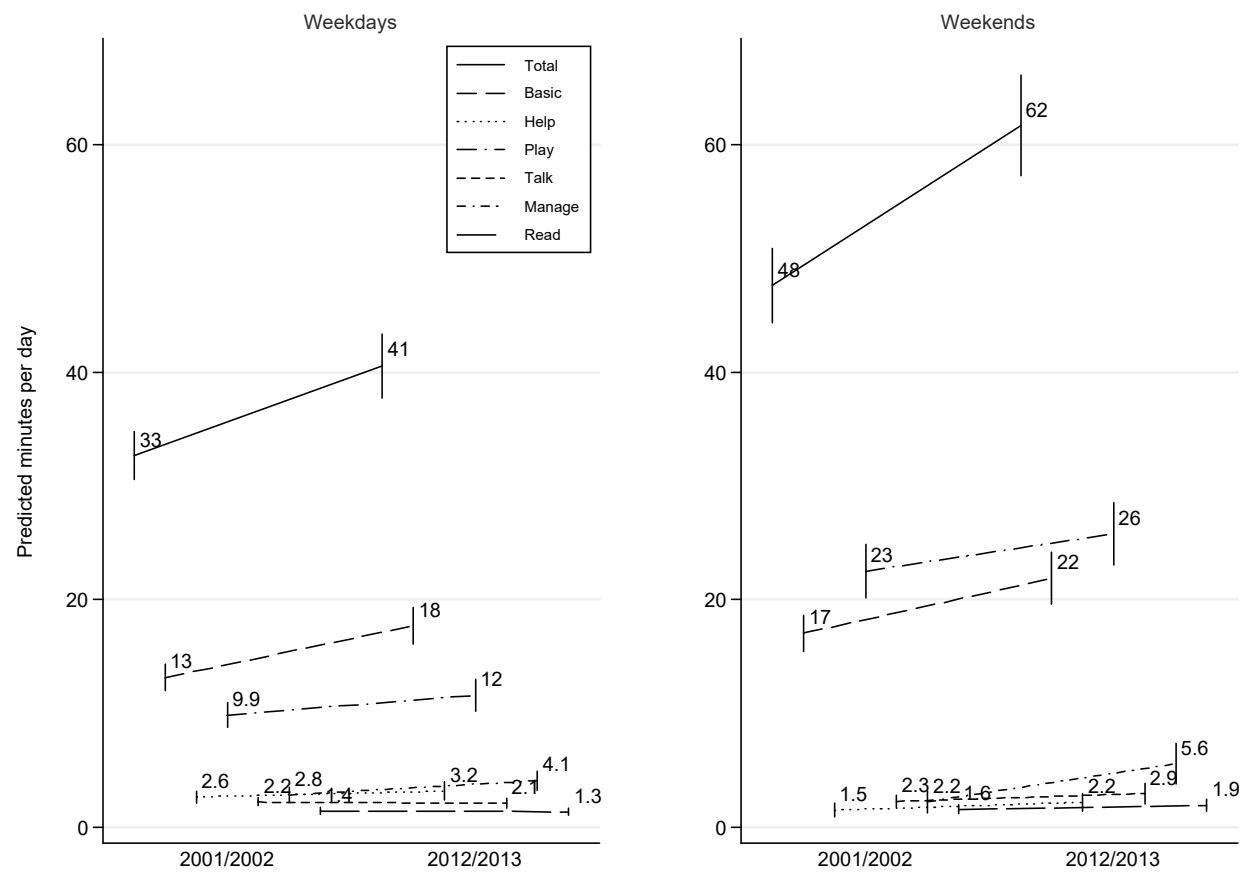

Note: Predictions and 95\%-confidence intervals are calculated as margins at the means from the regression models in Table A3. Source: GTUS 2001/2002, 2012/2013, own calculations. A colorized and resizable figure is available in the supplement to this article at http://dx.doi.org/10.20378/irbo58338.

On weekends, fathers' time for total childcare has significantly increased by about 14 minutes. Time for basic childcare and for managerial activities with and for children has also increased significantly by about 5 and 3 minutes, respectively.

These findings basically mirror the trends that could have been expected from the existing literature. After a period of little change in childcare time between 1991/1992 and $2001 / 2002$, childcare time in Germany slightly increased again in the early 2000s. However, in contrast to findings from other countries, especially the United States (Altintas 
2016), time for developmental childcare activities - helping children with homework, explaining things to children, talking to and with children, reading to and with children and telling them stories, or managerial activities - has remained on a rather low level in terms of minutes per weekday, with about 30 minutes for mothers and 10 minutes for fathers in 2012/2013 (on weekends: 18 minutes for mothers and 12 minutes for fathers). Evidently, there has been virtually no change in these developmental activities over our observation period.

\section{Stratification of childcare time in Germany, 2001-2013}

Figures 3 and 4 show average marginal effects and 95\% confidence intervals of our main independent variable - education - on the seven time budgets for childcare for mothers and fathers and for weekdays and weekend days.

Figure 3: Education gradients of mothers' childcare time for weekdays and weekends

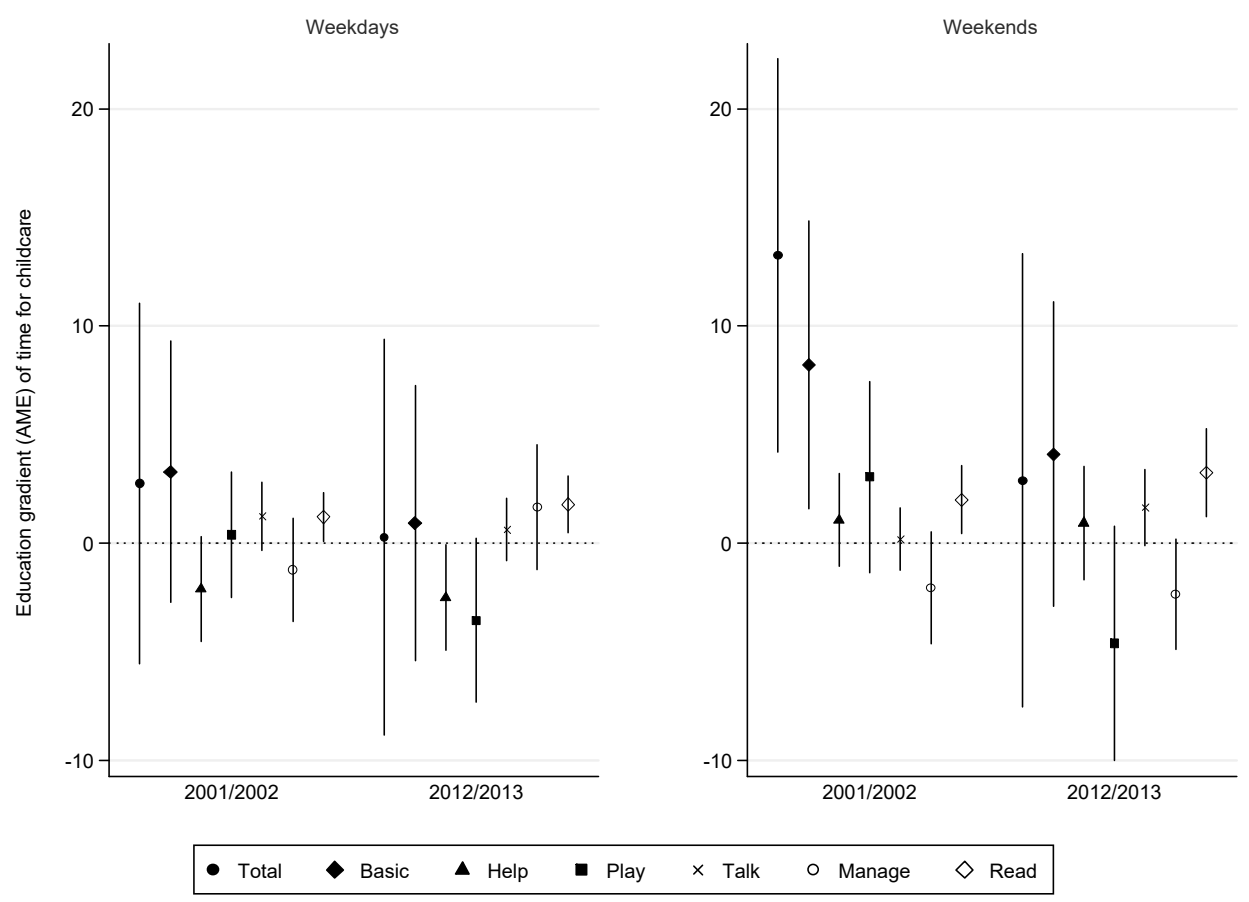

Note: Average marginal effects of education and $95 \%$-confidence intervals from the regression models in Table A2. Source: GTUS 2001/2002, 2012/2013, own calculations. A colorized and resizable figure is available in the supplement to this article at http://dx.doi.org/10.20378/irbo58338.

For mothers (Figure 3), we do not find a significant education gradient in time use on weekdays for total childcare, basic childcare, playing with children, talking with children and managing activities for the child in $2001 / 2002$. However, there is a positive education 
gradient for reading time in 2001/2002 and in 2012/2013: mothers with a university degree significantly spend more time reading with their children. Additionally, there is a negative education gradient for helping children in 2012/2013. On weekends, mothers display positive education gradients for total childcare time, basic childcare and reading in 2001/2002 and reading in 2012/2013.

For fathers, Figure 4 shows significantly (95\% level) positive education gradients on weekdays for total and basic childcare time in 2001/2002 and for talking, managing and reading in 2012/2013. On weekends, fathers with university degrees spend more time for total childcare, basic childcare, playing and reading in 2001/2002 and for total childcare, helping and reading in 2012/2013.

Figure 4: Education gradients of fathers' childcare time for weekdays and weekends

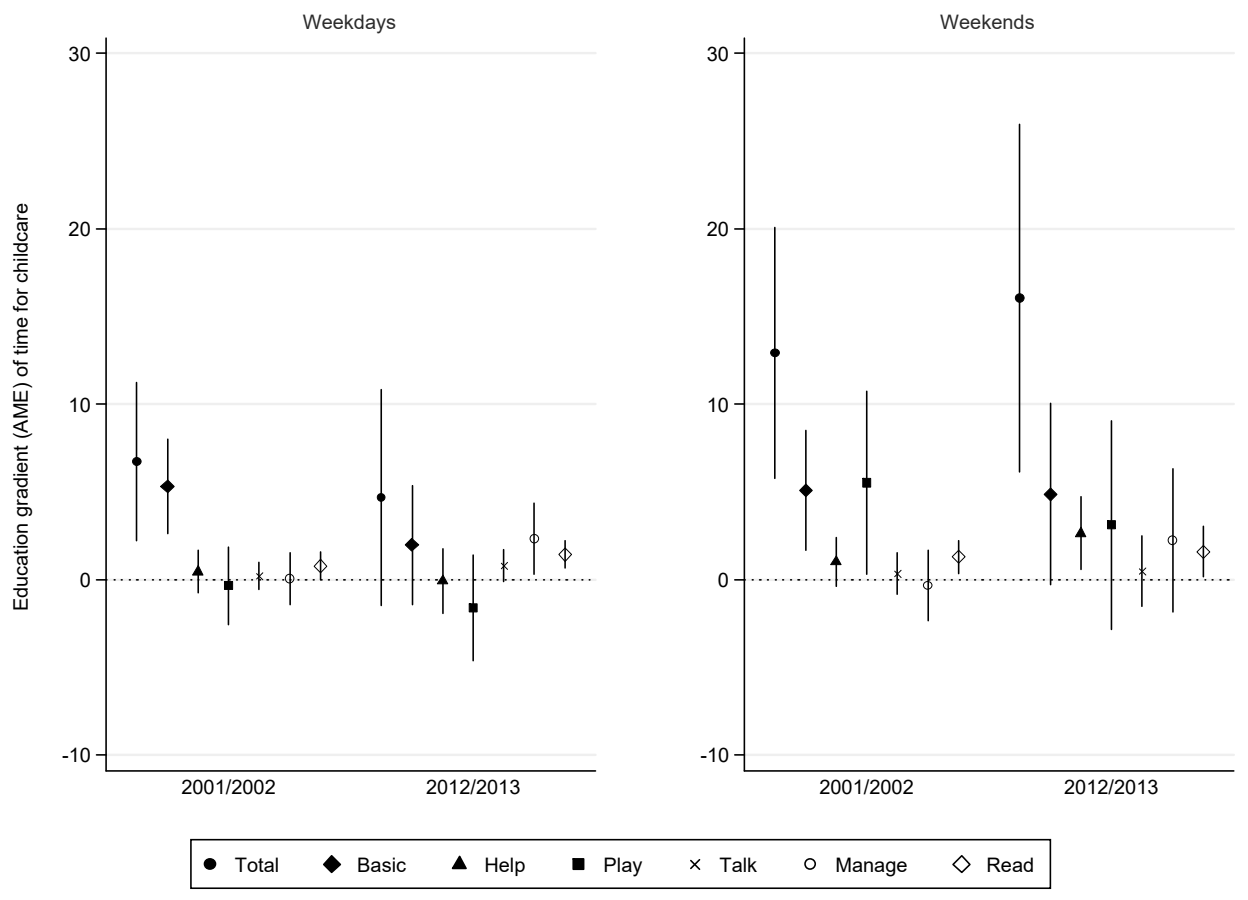

Note: Average marginal effects of education and $95 \%$-confidence intervals from the regression models in Table A3. Source: GTUS 2001/2002, 2012/2013, own calculations. A colorized and resizable figure is available in the supplement to this article at http://dx.doi.org/10.20378/irbo58338.

Yet, one has to note that the absolute time budgets for reading with children on weekdays and weekends are rather low and do not exceed the level of a few minutes per day on average. Still, the positive education gradient for reading with children is consistently prevalent in all cases, given that men's gradient on weekdays in 2001/2002 is significant at the $90 \%$ level. 


\section{Decomposition of childcare time in Germany, 2001-2013}

Table 1 reports the results of the decomposition analysis. The table shows the coefficients of the decomposition models for each of the seven time budgets for childcare, along with asterisks that indicate if the coefficient is statistically significant or not. The coefficients for "Total change" in the first row of each section (by gender and part of the week) of Table 1 show slightly more significant change than the predicted estimates in Figures 1, 2 which are based on Tables A-3, A-4. However, this does not affect the interpretation of the patterns found in the decomposition analysis.

Table 1: Results of the decomposition analysis for mothers and fathers on weekdays and weekends, 2001/2002-2012/2013

\begin{tabular}{|c|c|c|c|c|c|c|c|}
\hline & Total & Basic & Help & Play & Talk & Manage & Read \\
\hline & \multicolumn{7}{|c|}{ Women } \\
\hline & \multicolumn{7}{|c|}{ Weekdays } \\
\hline Total change & $12.7^{\star \star \star}$ & $6.1^{\star \star \star}$ & -0.8 & $4.2^{\star \star \star}$ & -0.1 & 1.6 & 0.6 \\
\hline Characteristics & -0.2 & 0.2 & -0.6 & 0.3 & -0.3 & -0.4 & $0.3^{\star *}$ \\
\hline University degree & -0.0 & 0.0 & $-0.1^{*}$ & $-0.2^{*}$ & 0.0 & 0.1 & $0.1^{* *}$ \\
\hline Coefficients & $13.0^{* \star *}$ & $5.9^{\star \star \star}$ & -0.2 & $3.9^{\star \star \star}$ & 0.1 & $2.0^{*}$ & 0.3 \\
\hline University degree & -0.6 & -0.6 & -0.0 & $-1.0^{\star}$ & -0.1 & 0.7 & 0.1 \\
\hline \multirow[t]{2}{*}{ Constant } & 7.5 & -7.0 & -1.4 & 2.0 & 4.9 & 8.4 & 2.8 \\
\hline & \multicolumn{7}{|c|}{ Weekends } \\
\hline Total change & $14.0^{\star \star \star}$ & $4.9^{\star *}$ & 1.1 & $5,7^{\star \star \star}$ & 0.5 & 0.7 & 0.1 \\
\hline Characteristics & -0.1 & 0.5 & -0.0 & 0.1 & 0.1 & $-1.1^{\star \star}$ & $0.4^{* *}$ \\
\hline University degree & 0.1 & 0.2 & 0.0 & -0.2 & $0.1^{*}$ & -0.1 & $0.1^{* * *}$ \\
\hline Coefficients & $14.1^{* \star \star}$ & $4.4^{*}$ & 1.1 & $5.6^{\star *}$ & 0.4 & 1.8 & -0.4 \\
\hline University degree & -2.3 & -0.9 & 0.1 & $-1.9^{\star}$ & 0.4 & -0.0 & 0.3 \\
\hline \multirow[t]{3}{*}{ Constant } & 17.4 & -12.9 & 0.6 & 11.3 & 5.9 & 9.9 & 3.0 \\
\hline & \multicolumn{7}{|c|}{ Men } \\
\hline & \multicolumn{7}{|c|}{ Weekdays } \\
\hline Total change & $7.9^{* \star *}$ & $4.6^{\star \star \star}$ & 0.5 & $1.7^{*}$ & -0.1 & $1.3^{*}$ & -0.1 \\
\hline Characteristics & 0.6 & -0.4 & 0.2 & 0.3 & $0.2^{*}$ & 0.0 & 0.0 \\
\hline University degree & -0.1 & -0.0 & 0.0 & 0.0 & -0.0 & $-0.0^{\star *}$ & $-0.0^{* * *}$ \\
\hline Coefficients & $7.3^{* * *}$ & $4.9^{* \star *}$ & 0.3 & 1.4 & -0.3 & $1.2^{*}$ & -0.1 \\
\hline University degree & -0.8 & -1.1 & -0.3 & -0.3 & 0.1 & $0.7^{*}$ & 0.2 \\
\hline \multirow[t]{2}{*}{ Constant } & 9.4 & $16.7^{\star \star}$ & -5.3 & $12.3^{*}$ & $-5.0^{* *}$ & -2.4 & $-3.3^{*}$ \\
\hline & \multicolumn{7}{|c|}{ Weekends } \\
\hline Total change & $14.1^{\star \star \star}$ & $4.8^{\star \star \star}$ & 0.7 & 3.3 & 0.7 & $3.3^{\star \star}$ & 0.3 \\
\hline Characteristics & 0.6 & -0.1 & -0.2 & 0.9 & 0.4 & -0.5 & 0.1 \\
\hline University degree & -0.5 & $-0.2+$ & $-0.1^{* *}$ & -0.1 & -0.0 & -0.1 & $-0.1^{*}$ \\
\hline Coefficients & $13.5^{\star \star \star}$ & $4.9^{\star \star}$ & $0.9+$ & 2.4 & 0.3 & $3.8^{\star \star}$ & 0.2 \\
\hline University degree & 0.9 & 0.0 & 0.5 & -0.7 & 0.0 & 0.7 & 0.0 \\
\hline Constant & 29.7 & 13.7 & 0.2 & 23.6 & -1.3 & -4.7 & -2.5 \\
\hline
\end{tabular}

Note: Coefficients of the decomposition (reduced table, coefficients for education only), and significance levels: $* \mathrm{p}<.05, * * \mathrm{p}<.01, * * * \mathrm{p}<.001$. Same regression equation as in Tables A-3, A-4 (but: binary for survey year and interaction of education and survey year are dropped). Source: GTUS 2001/2002, 2012/2013, own calculations. A full table with all coefficients of the decomposition analysis is available in the supplement to this article at http://dx.doi.org/10.20378/irbo50338. 
For mothers, we find that slightly more than the total observed shift in total childcare time $(102 \%$, that is $13.0 / 12.7 * 100)$ is significantly explained by differences in coefficients. About $-2 \%$ of the differences in mothers' total childcare time is due to differences in the means of the covariates (not significant), with no significant differences in intercepts. Thus, behavioral change operates in a different direction than demographical change. Equalizing education would not be expected to increase the shift in childcare between 2001/2002 and 2012/2013 and, moreover, if women in 2012/2013 with a university degree behaved in the same way as in $2001 / 2002$, total childcare would have significantly decreased (both coefficients not significant). The pattern for basic childcare and playing time with children is basically identical. Regarding reading time, the differences in the means of mothers' characteristics, and especially the increasing share of mothers with a university degree significantly explain differences between 2001/2002 and 2012/2013 for weekdays and weekends.

For fathers, only the change in coefficients contributes significantly to explaining the change in total and basic childcare time, accounting for about $92 \%$ and $107 \%$ of total change, respectively. This holds for both weekdays and weekend days in similar fashion.

Overall, if there is significant change in time use for childcare, the decomposition analysis reveals that this change can be explained by a change in coefficients and not in terms of changing characteristics. This finding supports the explanation of changing time use due to 'behavioral shifts' for mothers and fathers, on weekdays and weekends, as it has been documented for other western countries. Furthermore, this finding updates Berghammer's (2013) study, who has not found significant change in behavior or in demographics.

\section{Conclusions}

After experiencing a decade of stability between 1990 and 2000 (Berghammer 2013), German society has seen an increase in mothers' and fathers' total time for childcare over the first decade of the 2000s. This increase mirrors the development of time use for children in the western world (Dotti Sani/Treas 2016) and is theoretically in line with the emergence and diffusion of parenting ideologies that promote and demand active parental investments in their children. The increase in time use for total childcare can be traced back to changes in a few specific childcare activities and is not due to a proportional change in all singular childcare tasks. In particular, there has been no increase and perpetually low absolute time budgets of primary developmental childcare.

Contrary to other countries, but in line with some previous findings for Germany, there is no evidence of an overall education gradient of childcare time over the observation period. Yet, we showed a positive education gradient for reading time. Highly educated mothers and fathers spend significantly more time reading to their children; although the absolute time budgets of this (primary) activity are only of symbolic relevance. However, reading is one of the most important developmental activities for children (Bianchi/Robinson 1997; Leibowitz 1977), and parental support and investment here is of particular importance for skill and language acquisition (e.g., Stanovich 1986). For this particular activity only, the notion of 'diverging destinies' seems to be relevant for Germany - a society, in which the intergenerational transmission of educational levels and 
social status has always been much more salient than in other countries (Heineck/Riphahn 2009; Pfeffer 2008).

Our decomposition analysis yielded a concise pattern about the relative contribution of behavioral or demographical change to the development of childcare time in Germany. If there is significant change, it is driven by behavioral rather than demographical shifts. This pattern fits to international research which rather unanimously emphasized the relative importance of behavioral change over the decades (Sandberg/Hofferth 2001; Sayer/ Bianchi/Robinson 2004).

Taken together, our empirical findings of childcare time in Germany do not provide evidence of dynamics and stratification, but rather of stability and similarity across parents' educational levels. Yet, there is slight evidence for processes of 'diverging destinies' when looking at the specific time budget for reading with children. To assess whether this trend holds over time will require further data. In the meantime, however, there should be research about how parental time for specific activities actually affects children's outcomes.

\section{Acknowledgments}

This study was funded by the Bavarian State Ministry of Labor and Social Affairs, Family and Integration within the annual working program of the State Institute for Family Research (ifb) at the University of Bamberg in 2016 and 2017. The content of this article does not reflect the official opinion of the Bavarian State Ministry of Labor and Social Affairs, Family and Integration. Responsibility for the information and views expressed herein lies entirely with the authors. Earlier versions of this paper were presented at the European Population Conference on September 3, 2016, in Mainz, Germany (Session 117, Child development) and at the Annual Meeting of the Population Association of America on April 28, 2017, in Chicago, USA (Session P9).

\section{References}

Altintas, E. (2015). Educational differences in fathers' time with children in two parent families: Time diary evidence from the United States. Family Science, 6, 1, pp. 293-301. doi:10.1080/19424620.2015.1082340.

Altintas, E. (2016). The widening education gap in developmental child care activities in the United States, 1965-2013. Journal of Marriage and Family, 78, 1, pp. 26-42. doi:10.1111/jomf.12254.

Berghammer, C. (2013). Keine Zeit für Kinder? Veränderungen in der Kinderbetreuungszeit von Eltern in Deutschland und Österreich [No time for children? Changes in parents' child care time in Germany and Austria; in German]. Zeitschrift für Soziologie 42, 1, pp. 52-73. doi:10.1515/zfsoz-2013-0105.

Bianchi, S. M. \& Robinson, J. P. (1997). What did you do today? Children's use of time, family composition, and the acquisition of social capital. Journal of Marriage and Family, 59, 2, pp. 332-344. doi: $10.2307 / 353474$.

Bonke, J. \& Esping-Andersen, G. (2011). Family investments in children - Productivities, preferences, and parental child care. European Sociological Review, 27, 1, pp. 43-55. doi:10.1093/esr/jcp054.

Craig, L., Powell, A. \& Smyth, C. (2014). Towards intensive parenting? Changes in the composition and determinants of mothers' and fathers' time with children 1992-2006. British Journal of Sociology, 65, 3, pp. 555-579. doi:10.1111/1468-4446.12035. 
Dotti Sani, G.M. \& Treas, J. (2016). Educational gradients in parent's child-care time across countries, 1965-2012. Journal of Marriage and Family, 78, 4, pp. 1083-1096. doi:10.1111/jomf.12305.

Ehling, M., Holz, E. \& Kahle I. (2001). Erhebungsdesign der Zeitbudgeterhebung 2001/2002 [Design of the German Time Use Study 2001/2001; in German]. Wirtschaft und Statistik, 6/2001 pp. 427-436. https://www.destatis.de/DE/Publikationen/WirtschaftStatistik/WirtschaftsrZeitbudget/ Erhebungsdesign62001.pdf?_blob=publicationFile [Retrieved: 2017-03-10].

England, P. \& Srivastava, A. (2013). Educational differences in US parents' time spent in child care: The role of culture and cross-spouse influence. Social Science Research, 42, 4, pp. 971-988. doi:10.1016/j.ssresearch.2013.03.003.

Foster, G. \& Kalenkoski, C.M. (2013). Tobit or OLS? An empirical evaluation under different diary window lengths. Applied Economics, 45, 20, pp. 2994-3010. doi:10.1080/00036846.2012.690852.

Gauthier, A. H., Smeeding, T. M. \& Furstenberg, F. F. (2004). Are parents investing less time in children? Trends in selected industrialized countries. Population and Development Review, 30, 4, pp. 647-672. doi:10.1111/j.1728-4457.2004.00036.x.

Guryan, J., Hurst, E. \& Kearney, M. (2008). Parental education and parental time with children. Journal of Economic Perspectives, 22, 3, pp. 23-46. doi:10.1257/jep.22.3.23.

Hallberg, D. \& Klevmarken, A. (2003). Time for children: A study of parent's time allocation. Journal of Population Economics, 16, 2, pp. 205-226. doi:10.1007/s001480200133.

Heineck, G. \& Riphahn, R. (2009). Intergenerational transmission of educational attainment in Germany - The last five decades. Journal of Economics and Statistics, 229, 1, pp. 36-60. doi:10.1515/jbnst-2009-0104.

Hofferth, S. L. (2006). Response bias in a popular indicator of reading to children. Sociological Methodology, 36, 1, pp. 301-315. doi:10.1111/j.1467-9531.2006.00182.x.

Kan, M. Y., \& Pudney, S. (2008). Measurement error in stylized and diary data on time use. Sociological Methodology, 38, 1, pp. 101-132. doi:10.1111/j.1467-9531.2008.00197.x.

Kalil, A., Ryan, R., \& Corey, M. (2012). Diverging destinies: Maternal education and the developmental gradient in time with children. Demography, 49, 4, pp. 1361-1383. doi:10.1007/s13524-012-0129-5.

Kitterød, R. H. (2001). Does the recoding of parallel activities in time use diaries affect the way people report their main activities? Social Indicators Research, 56, 2, pp. 145-178. doi:10.1023/A:1012289811886.

Lareau, A. (2011). Unequal childhoods. class, race, and family life. University of California Press (2 ${ }^{\text {nd }}$ edition). www.jstor.org/stable/10.1525/j.ctt1ppgj4.

Leibowitz, A. (1974). Home investments in children. Journal of Political Economy; 82, 2, pp. S111-S131. doi:10.1086/260295.

Leibowitz, A. (1977). Parental inputs and children's achievement. Journal of Human Resources, 12, 2, pp. 247-267. doi:10.2307/145387.

Maier, L. (2014). Methodik und Durchführung der Zeitverwendungserhebung 2012/2013 [Design of the German Time Use Study 2012/2013; in German]. Wirtschaft und Statistik, 11/2014, pp. 672-679. https://www.destatis.de/DE/Publikationen/WirtschaftStatistik/WirtschaftsrZeitbudget/ Zeitverwendungserhebung_112014.pdf;jsessionid=4FB215004419E30C84519E0311F76B7B. cae1?_blob=publicationFile [Retrieved: 2017-03-10].

McLanahan, S. (2004). Diverging destinies: How children are faring under the Second Demographic Transition. Demography, 41, 4, pp. 607-627. doi:10.1353/dem.2004.0033.

Monna, B. \& Gauthier, A. H. (2008). A review of the literature in the social and economic determinants of parental time. Journal of Family and Economic Issues, 29, 4, pp. 634-653. doi:10.1007/s10834-008-9121-z.

Pfeffer, F. T. (2008). Persistent inequality in educational attainment and its institutional context. European Sociological Review, 24, 5, pp. 543-565. doi:10.1093/esr/jen026.

Powers, D. A., Yoshioka, H., \& Yun, M.-S. (2011). mvdcmp: Multivariate decomposition for nonlinear response models. The Stata Journal, 11, 4, pp. 556-576.

http://www.stata-journal.com/sjpdf.html?articlenum=st0241. 
Sayer, L. C., Bianchi, S. M., \& Robinson, J. P. (2004). Are parents investing less in children? Trends in mothers' and fathers' time with children. American Journal of Sociology, 110, 1, pp. 1-43. doi:10.1086/386270.

Sayer, L. C., Gauthier, A. H., \& Furstenberg, F. F. (2004). Educational differences in parents' time with children: Cross-national variations. Journal of Marriage and Family, 66, 5, pp. 1152-1169. doi:10.1111/j.0022-2445.2004.00084.x.

Stanovich, K. E. (1986). Matthew effects in reading: Some consequences of individual differences in the acquisition of literacy. Reading Research Quarterly, 21, 421, pp. 360-407. http://www.jstor.org/stable/747612.

Statistisches Bundesamt (2015). Wie die Zeit vergeht. Ergebnisse zur Zeitverwendung in Deutschland 2012/2013 [How time flies. Time use in Germany 2012/2013; in German]. Wiesbaden: Statistisches Bundesamt.

https://www.destatis.de/DE/PresseService/Presse/Pressekonferenzen/2015/zeitverwendung/ Pressebroschuere_zeitverwendung.pdf;jsessionid=63BE92F7D0A763FDF9494E913CB6DF52. InternetLive2?_blob=publicationFile [Retrieved: 2017-11-02].

Statistisches Bundesamt (2017). Wie die Zeit vergeht. Analysen zur Zeitverwendung in Deutschland. Beiträge zur Ergebniskonferenz der Zeitverwendungserhebung 2012/ 2013 am 5./6. Oktober 2016 in Wiesbaden [How time flies. Analyses of time use in Germany 2012/2013; in German].Wiesbaden: Statistisches Bundesamt.

https://www.destatis.de/DE/Publikationen/Thematisch/EinkommenKonsumLebensbedingungen/Zeit budgeterhebung/TagungsbandWieDieZeitVergeht5639103169004.pdf?_blob=publicationFile [Retrieved: 2017-10-02].

Stewart, J. (2009). Tobit or not tobit? U.S. Bureau of Labor Statistics. (BLS Working Papers, No. 432. http://www.bls.gov/ore/pdf/ec090100.pdf [Retrieved: 2017-03-08].

Williams, R. (2012). Using the margins command to estimate and interpret adjusted predictions and marginal effects. The Stata Journal, 12, 21, pp. 308-331.

http://www.stata-journal.com/sjpdf.html?articlenum=st0260.

Submitted on/Eingereicht am: 31.05.2017

Accepted on/Angenommen am: 04.11.2017

Anschriften des Autors und der Autorin/Addresses of the authors:

Dr. Florian Schulz (Corresponding author/Korrespondenzautor)

State Institute of Family Research at the University of Bamberg (ifb), and

University of Bamberg (Demography)

Heinrichsdamm 4

96047 Bamberg

Germany/Deutschland

E-Mail/Email: florian.schulz@ifb.uni-bamberg.de

Prof. Dr. Henriette Engelhardt-Wölfler

University of Bamberg (Demography), and

State Institute of Family Research at the University of Bamberg (ifb)

Feldkirchenstr. 21

96052 Bamberg

Germany/Deutschland

E-Mail/Email: henriette.engelhardt-woelfler@uni-bamberg.de 


\section{Appendix}

Table A-1: Sample characteristics, by sex of respondent, survey year, and weekdays and weekends

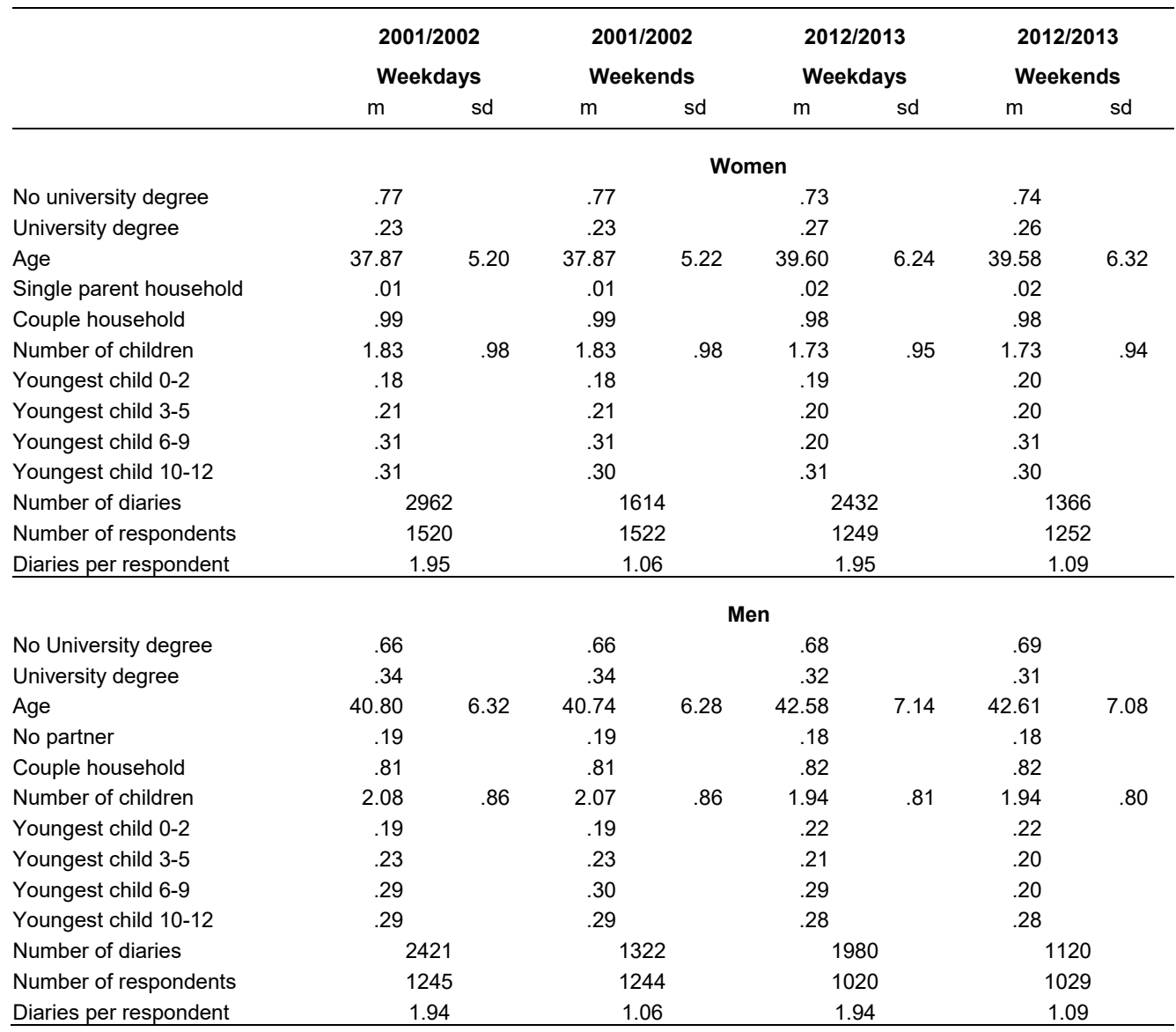

Note: All respondent characteristics are based on the sample of diaries which is used for the analyses. Compared to the pure respondent sample, the differences are negligible. Source: GTUS 2001/2002, 2012/2013; own calculations. 
Table A-2: Average minutes and participation rates per weekdays and weekend days of each childcare activity, by sex, survey year, education

\begin{tabular}{|c|c|c|c|c|c|c|c|c|c|c|c|c|c|c|}
\hline & \multicolumn{2}{|c|}{ Total } & \multicolumn{2}{|c|}{ Basic } & \multicolumn{2}{|c|}{ Help } & \multicolumn{2}{|c|}{ Play } & \multicolumn{2}{|c|}{ Talk } & \multicolumn{2}{|c|}{ Manage } & \multicolumn{2}{|c|}{ Read } \\
\hline & $\mathrm{m}$ & $\mathrm{p}$ & $\mathrm{m}$ & $\mathrm{p}$ & $\mathrm{m}$ & $\mathrm{p}$ & $\mathrm{m}$ & $\mathrm{p}$ & $\mathrm{m}$ & $\mathrm{p}$ & $\mathrm{m}$ & $\mathrm{p}$ & $\mathrm{m}$ & p \\
\hline & \multicolumn{14}{|c|}{ Women - Weekdays } \\
\hline $2001 / 2002$ & 88 & .84 & 43 & .69 & 12 & .28 & 14 & .24 & 6 & .23 & 9 & .15 & 3 & .13 \\
\hline No univ. deg. & 88 & .84 & 42 & .70 & 12 & .29 & 14 & .24 & 6 & .22 & 9 & .15 & 3 & .12 \\
\hline Univ. deg. & 88 & .83 & 43 & .68 & 10 & .24 & 14 & .25 & 7 & .26 & 8 & .17 & 4 & .17 \\
\hline $2012 / 2013$ & 101 & .85 & 49 & .73 & 11 & .24 & 19 & .26 & 6 & .22 & 11 & .24 & 4 & .15 \\
\hline No univ. deg. & 98 & .85 & 46 & .73 & 12 & .25 & 19 & .26 & 6 & .21 & 10 & .23 & 3 & .13 \\
\hline \multirow[t]{2}{*}{ Univ. deg. } & 110 & .85 & 55 & .74 & 9 & .21 & 18 & .28 & 6 & .23 & 13 & .29 & 6 & .20 \\
\hline & \multicolumn{14}{|c|}{ Women - Weekends } \\
\hline $2001 / 2002$ & 71 & .72 & 37 & .60 & 4 & .10 & 18 & .27 & 3 & .12 & 4 & .04 & 3 & .12 \\
\hline No univ. deg. & 68 & .72 & 35 & .59 & 4 & .10 & 17 & .26 & 3 & .12 & 5 & .05 & 3 & .11 \\
\hline Univ. deg. & 82 & .73 & 44 & .62 & 5 & .10 & 20 & .30 & 3 & .14 & 2 & .03 & 5 & .16 \\
\hline $2012 / 2013$ & 85 & .76 & 42 & .64 & 5 & .10 & 23 & .29 & 4 & .12 & 5 & .06 & 3 & .12 \\
\hline No univ. deg. & 82 & .74 & 39 & .62 & 5 & .09 & 24 & .29 & 3 & .11 & 6 & .06 & 2 & .10 \\
\hline \multirow[t]{2}{*}{ Univ. deg. } & 95 & .80 & 50 & .70 & 6 & .13 & 22 & .30 & 5 & .15 & 3 & .06 & 6 & .17 \\
\hline & \multicolumn{14}{|c|}{ Men - Weekdays } \\
\hline $2001 / 2002$ & 33 & .55 & 13 & .36 & 3 & .07 & 10 & .20 & 2 & .10 & 3 & .05 & 1 & .06 \\
\hline No univ. deg. & 31 & .53 & 11 & .34 & 2 & .07 & 10 & .20 & 2 & .09 & 3 & .05 & 1 & .05 \\
\hline Univ. deg. & 37 & .60 & 16 & .44 & 3 & .08 & 9 & .20 & 2 & .11 & 3 & .05 & 2 & .08 \\
\hline $2012 / 2013$ & 41 & .59 & 18 & .44 & 3 & .07 & 12 & .19 & 2 & .09 & 4 & .10 & 1 & .06 \\
\hline No univ. deg. & 38 & .56 & 17 & .41 & 3 & .07 & 12 & .19 & 2 & .08 & 3 & .09 & 1 & .04 \\
\hline \multirow[t]{2}{*}{ Univ. deg. } & 46 & .66 & 20 & .50 & 3 & .07 & 11 & .22 & 3 & .11 & 6 & .11 & 2 & .11 \\
\hline & \multicolumn{14}{|c|}{ Men - Weekends } \\
\hline $2001 / 2002$ & 48 & .56 & 17 & .39 & 1 & .03 & 23 & .29 & 2 & .09 & 2 & .02 & 2 & .07 \\
\hline No univ. deg. & 44 & .54 & 15 & .37 & 1 & .03 & 21 & .27 & 2 & .08 & 2 & .02 & 1 & .05 \\
\hline Univ. deg. & 55 & .61 & 20 & .44 & 2 & .05 & 26 & .33 & 3 & .10 & 2 & .02 & 2 & .09 \\
\hline $2012 / 2013$ & 62 & .59 & 22 & .44 & 2 & .04 & 26 & .30 & 3 & .08 & 6 & .05 & 2 & .06 \\
\hline No univ. deg. & 56 & .56 & 20 & .40 & 1 & .03 & 25 & .29 & 3 & .07 & 5 & .05 & 1 & .05 \\
\hline Univ. deg. & 74 & .68 & 26 & .51 & 4 & .06 & 28 & .34 & 3 & .10 & 7 & .07 & 3 & .09 \\
\hline
\end{tabular}

Note: $\mathrm{m}$ mean; p percentage of respondents who reported positive activity time different from zero. Source: GTUS 2001/2002, 2012/2013; own calculations.

Table A-3: OLS regressions of mothers' time budgets for childcare, separate estimations for weekdays and weekends

\begin{tabular}{lccccccc}
\hline & $\begin{array}{c}(\mathbf{1}) \\
\text { Total }\end{array}$ & $\begin{array}{c}(\mathbf{2}) \\
\text { Basic }\end{array}$ & $\begin{array}{c}(\mathbf{3}) \\
\text { Help }\end{array}$ & $\begin{array}{c}(\mathbf{4}) \\
\text { Play }\end{array}$ & $\begin{array}{c}(\mathbf{5}) \\
\text { Talk }\end{array}$ & $\begin{array}{c}(6) \\
\text { Manage }\end{array}$ & $\begin{array}{c}(\mathbf{7}) \\
\text { Read }\end{array}$ \\
\hline \multirow{3}{*}{ University degree $^{\mathrm{a}}$} & \multicolumn{7}{c}{ Weekdays } \\
& 2.74 & 3.28 & -2.12 & 0.38 & 1.22 & -1.24 & $1.20^{*}$ \\
Age & $(4.24)$ & $(3.07)$ & $(1.23)$ & $(1.48)$ & $(0.80)$ & $(1.21)$ & $(0.58)$ \\
& -0.50 & $-0.42^{*}$ & 0.07 & -0.23 & 0.02 & -0.09 & $0.08^{*}$ \\
Single $^{\mathrm{b}}$ & $(0.31)$ & $(0.21)$ & $(0.08)$ & $(0.13)$ & $(0.06)$ & $(0.10)$ & $(0.04)$ \\
& $12.14^{* *}$ & $7.64^{* *}$ & 0.15 & -1.71 & $2.68^{* * *}$ & 2.70 & 0.32 \\
Children in household $^{*}$ & $(3.99)$ & $(2.77)$ & $(1.23)$ & $(1.59)$ & $(0.79)$ & $(1.44)$ & $(0.51)$ \\
& $5.15^{* *}$ & 2.27 & $2.46^{* * *}$ & $-3.67^{* * *}$ & $1.56^{* * *}$ & $2.08^{* *}$ & -0.01 \\
& $(1.76)$ & $(1.29)$ & $(0.53)$ & $(0.63)$ & $(0.30)$ & $(0.74)$ & $(0.24)$
\end{tabular}




\begin{tabular}{|c|c|c|c|c|c|c|c|}
\hline & $\begin{array}{c}(1) \\
\text { Total } \\
\end{array}$ & $\begin{array}{c}(2) \\
\text { Basic }\end{array}$ & $\begin{array}{c}(3) \\
\text { Help }\end{array}$ & $\begin{array}{c}\text { (4) } \\
\text { Play } \\
\end{array}$ & $\begin{array}{c}(5) \\
\text { Talk }\end{array}$ & $\begin{array}{c}(6) \\
\text { Manage } \\
\end{array}$ & $\begin{array}{c}(7) \\
\text { Read }\end{array}$ \\
\hline \multicolumn{8}{|c|}{ Weekdays } \\
\hline Youngest child $3-5^{c}$ & $\begin{array}{l}-95.56^{\star \star \star} \\
(5.45)\end{array}$ & $\begin{array}{c}-74.40^{\star \star \star} \\
(4.42)\end{array}$ & $\begin{array}{c}2.37^{*} \\
(0.99)\end{array}$ & $\begin{array}{l}-22.28^{* * *} \\
(2.40)\end{array}$ & $\begin{array}{r}1.40^{*} \\
(0.61)\end{array}$ & $\begin{array}{l}-3.21 \\
(1.64)\end{array}$ & $\begin{array}{c}0.37 \\
(0.69)\end{array}$ \\
\hline Youngest child $6-9^{c}$ & $\begin{array}{c}-120.60^{\star \star * *} \\
(5.49)\end{array}$ & $\begin{array}{l}-94.82^{\star \star \star} \\
(4.32)\end{array}$ & $\begin{array}{l}12.59^{* \star \star} \\
(1.27)\end{array}$ & $\begin{array}{l}-36.04^{\star \star \star} \\
(2.27)\end{array}$ & $\begin{array}{l}3.666^{\star \star \star} \\
(0.66)\end{array}$ & $\begin{array}{c}-4.23^{*} \\
(1.69)\end{array}$ & $\begin{array}{l}-2.41^{\star \star \star} \\
(0.68)\end{array}$ \\
\hline Youngest child $10-12^{c}$ & $\begin{array}{c}-159.04^{* \star *} \\
(5.49)\end{array}$ & $\begin{array}{c}-112.90^{\star \star \star} \\
(4.30)\end{array}$ & $\begin{array}{l}7.13^{* * *} \\
(1.39)\end{array}$ & $\begin{array}{l}-41.88^{* * *} \\
(2.33)\end{array}$ & $\begin{array}{l}4.05^{* \star *} \\
(0.79)\end{array}$ & $\begin{array}{l}-9.21^{* \star *} \\
(1.64)\end{array}$ & $\begin{array}{l}-5.91^{* * *} \\
(0.65)\end{array}$ \\
\hline East Germany ${ }^{d}$ & $\begin{array}{c}-7.92^{*} \\
(3.40)\end{array}$ & $\begin{array}{l}-3.54 \\
(2.40)\end{array}$ & $\begin{array}{l}-3.05^{\star \star \star} \\
(0.84)\end{array}$ & $\begin{array}{l}-0.48 \\
(1.46)\end{array}$ & $\begin{array}{c}0.29 \\
(0.64)\end{array}$ & $\begin{array}{l}-0.99 \\
(1.03)\end{array}$ & $\begin{array}{c}-0.68 \\
(0.40)\end{array}$ \\
\hline Survey year $2012 / 2013^{e}$ & $\begin{array}{l}13.51^{\star \star \star} \\
(3.13)\end{array}$ & $\begin{array}{c}6.51^{* *} \\
(2.20)\end{array}$ & $\begin{array}{l}-0.22 \\
(0.96)\end{array}$ & $\begin{array}{l}4.94^{* \star \star} \\
(1.30)\end{array}$ & $\begin{array}{c}0.13 \\
(0.56)\end{array}$ & $\begin{array}{c}1.21 \\
(1.07)\end{array}$ & $\begin{array}{c}0.24 \\
(0.39)\end{array}$ \\
\hline Univ. degr. \# Surv. 2012 & $\begin{array}{l}-2.48 \\
(6.31)\end{array}$ & $\begin{array}{l}-2.36 \\
(4.50)\end{array}$ & $\begin{array}{l}-0.39 \\
(1.74)\end{array}$ & $\begin{array}{l}-3.94 \\
(2.43)\end{array}$ & $\begin{array}{l}-0.59 \\
(1.06)\end{array}$ & $\begin{array}{c}2.90 \\
(1.87)\end{array}$ & $\begin{array}{c}0.58 \\
(0.87)\end{array}$ \\
\hline Constant & $\begin{array}{l}201.84^{* * *} \\
(11.66)\end{array}$ & $\begin{array}{c}131.80^{* * *} \\
(8.87)\end{array}$ & $\begin{array}{l}-1.07 \\
(2.70) \\
\end{array}$ & $\begin{array}{l}58.50^{* * *} \\
(4.89)\end{array}$ & $\begin{array}{l}-1.34 \\
(1.71) \\
\end{array}$ & $\begin{array}{l}13.74^{* * *} \\
(3.64)\end{array}$ & $\begin{array}{c}2.40 \\
(1.37) \\
\end{array}$ \\
\hline Respondents & 2757 & 2757 & 2757 & 2757 & 2757 & 2757 & 2757 \\
\hline Observations & 5370 & 5370 & 5370 & 5370 & 5370 & 5370 & 5370 \\
\hline$\underline{\text { R-squared }}$ & 0.343 & 0.364 & 0.053 & 0.192 & 0.022 & 0.019 & 0.050 \\
\hline \multicolumn{8}{|c|}{ Weekends } \\
\hline University degree $^{a}$ & $\begin{array}{l}13.24^{* *} \\
(4.61)\end{array}$ & $\begin{array}{c}8.21^{*} \\
(3.38)\end{array}$ & $\begin{array}{c}1.06 \\
(1.10)\end{array}$ & $\begin{array}{c}3.05 \\
(2.24)\end{array}$ & $\begin{array}{c}0.18 \\
(0.72)\end{array}$ & $\begin{array}{l}-2.07 \\
(1.31)\end{array}$ & $\begin{array}{c}1.99^{*} \\
(0.80)\end{array}$ \\
\hline Age & $\begin{array}{c}-0.66^{*} \\
(0.33)\end{array}$ & $\begin{array}{l}-0.29 \\
(0.20)\end{array}$ & $\begin{array}{c}0.09 \\
(0.08)\end{array}$ & $\begin{array}{l}-0.46^{* *} \\
(0.17)\end{array}$ & $\begin{array}{c}0.06 \\
(0.05)\end{array}$ & $\begin{array}{c}-0.29^{*} \\
(0.14)\end{array}$ & $\begin{array}{l}0.17^{\star \star \star} \\
(0.04)\end{array}$ \\
\hline Single $^{b}$ & $\begin{array}{c}8.29 \\
(4.62)\end{array}$ & $\begin{array}{c}5.82^{*} \\
(2.79)\end{array}$ & $\begin{array}{l}-1.47 \\
(1.08)\end{array}$ & $\begin{array}{l}-4.32 \\
(2.32)\end{array}$ & $\begin{array}{c}2.29^{* *} \\
(0.74)\end{array}$ & $\begin{array}{c}4.84^{*} \\
(2.01)\end{array}$ & $\begin{array}{c}1.12 \\
(0.61)\end{array}$ \\
\hline Children in household & $\begin{array}{l}-0.24 \\
(1.89)\end{array}$ & $\begin{array}{c}1.44 \\
(1.30)\end{array}$ & $\begin{array}{c}0.49 \\
(0.39)\end{array}$ & $\begin{array}{l}-4.91^{\star \star \star} \\
(1.01)\end{array}$ & $\begin{array}{c}0.37 \\
(0.27)\end{array}$ & $\begin{array}{c}1.93^{* *} \\
(0.60)\end{array}$ & $\begin{array}{c}0.07 \\
(0.27)\end{array}$ \\
\hline Youngest child $3-5^{\mathrm{c}}$ & $\begin{array}{l}-77.78^{\star \star \star} \\
(5.78)\end{array}$ & $\begin{array}{l}-66.23^{* \star *} \\
(4.50)\end{array}$ & $\begin{array}{r}1.54^{*} \\
(0.66)\end{array}$ & $\begin{array}{l}-18.57^{\star \star \star} \\
(3.21)\end{array}$ & $\begin{array}{c}-0.12 \\
(0.76)\end{array}$ & $\begin{array}{c}4.02^{* \star \star} \\
(1.20)\end{array}$ & $\begin{array}{c}1.51 \\
(0.86)\end{array}$ \\
\hline Youngest child $6-9^{c}$ & $\begin{array}{c}-112.21^{\star \star \star} \\
(5.68)\end{array}$ & $\begin{array}{l}-88.49^{\star \star \star} \\
(4.34)\end{array}$ & $\begin{array}{l}6.73^{\star \star \star} \\
(1.07)\end{array}$ & $\begin{array}{l}-33.39^{\star \star \star} \\
(2.92)\end{array}$ & $\begin{array}{l}-0.17 \\
(0.72)\end{array}$ & $\begin{array}{l}5.88^{\star \star \star} \\
(1.60)\end{array}$ & $\begin{array}{l}-2.53^{* * *} \\
(0.74)\end{array}$ \\
\hline Youngest child $10-12^{c}$ & $\begin{array}{c}-139.41^{\star \star \star} \\
(5.91)\end{array}$ & $\begin{array}{c}-102.94^{\star \star \star} \\
(4.38)\end{array}$ & $\begin{array}{l}4.94^{\star \star \star} \\
(1.18)\end{array}$ & $\begin{array}{l}-41.02^{\star \star \star} \\
(3.05)\end{array}$ & $\begin{array}{c}-0.33 \\
(0.78)\end{array}$ & $\begin{array}{l}6.37^{* *} \\
(2.11)\end{array}$ & $\begin{array}{l}-5.85^{\star \star \star} \\
(0.71)\end{array}$ \\
\hline East Germany $^{\mathrm{d}}$ & $\begin{array}{l}-4.43 \\
(3.87)\end{array}$ & $\begin{array}{l}-1.95 \\
(2.56)\end{array}$ & $\begin{array}{c}1.72 \\
(1.02)\end{array}$ & $\begin{array}{l}-1.96 \\
(2.08)\end{array}$ & $\begin{array}{c}0.90 \\
(0.68)\end{array}$ & $\begin{array}{c}-2.40^{*} \\
(1.22)\end{array}$ & $\begin{array}{c}-0.06 \\
(0.49)\end{array}$ \\
\hline Survey year $2012 / 2013^{\mathrm{e}}$ & $\begin{array}{l}15.88^{\star \star *} \\
(3.50)\end{array}$ & $\begin{array}{c}5.01^{*} \\
(2.25)\end{array}$ & $\begin{array}{c}0.92 \\
(0.91)\end{array}$ & $\begin{array}{l}7.49^{* * *} \\
(1.88)\end{array}$ & $\begin{array}{c}0.01 \\
(0.51)\end{array}$ & $\begin{array}{c}1.77 \\
(1.46)\end{array}$ & $\begin{array}{c}-0.62 \\
(0.40)\end{array}$ \\
\hline Uni \# 2012/2013 & $\begin{array}{l}-10.37 \\
(7.07)\end{array}$ & $\begin{array}{l}-4.12 \\
(4.95)\end{array}$ & $\begin{array}{l}-0.14 \\
(1.74)\end{array}$ & $\begin{array}{r}-7.67^{*} \\
(3.55)\end{array}$ & $\begin{array}{c}1.46 \\
(1.15)\end{array}$ & $\begin{array}{l}-0.29 \\
(1.90)\end{array}$ & $\begin{array}{c}1.23 \\
(1.31)\end{array}$ \\
\hline Constant & $\begin{array}{l}185.86^{\star * *} \\
(12.34)\end{array}$ & $\begin{array}{l}115.30^{* * \star} \\
(8.04)\end{array}$ & $\begin{array}{l}-3.90 \\
(2.61) \\
\end{array}$ & $\begin{array}{l}71.28^{* \star \star} \\
(6.74)\end{array}$ & $\begin{array}{c}-0.08 \\
(1.85) \\
\end{array}$ & $\begin{array}{c}7.21 \\
(4.53) \\
\end{array}$ & $\begin{array}{l}-1.81 \\
(1.48) \\
\end{array}$ \\
\hline Respondents & 2769 & 2769 & 2769 & 2769 & 2769 & 2769 & 2769 \\
\hline Observations & 2968 & 2968 & 2968 & 2968 & 2968 & 2968 & 2968 \\
\hline R-squared & 0.317 & 0.379 & 0.023 & 0.153 & 0.007 & 0.010 & 0.060 \\
\hline
\end{tabular}

Note: Reference categories: ${ }^{\mathrm{a}}$ No university education, ${ }^{\mathrm{b}}$ Couple household, ${ }^{\mathrm{c}}$ Youngest child $0-2,{ }^{\mathrm{d}}$ West Germany, ${ }^{\mathrm{e}}$ Survey year $2001 / 2002$. Significance levels: ${ }^{*} \mathrm{p}<.05,{ }^{*} \mathrm{p}<.01,{ }^{* * *} \mathrm{p}<.001$. Source: GTUS 2001/2002 and 2012/2013; own calculations. 
Table A-4: OLS regressions of fathers' time budgets for childcare, separate estimations for weekdays and weekends

\begin{tabular}{|c|c|c|c|c|c|c|c|}
\hline & $\begin{array}{l}\text { (1) } \\
\text { Total }\end{array}$ & $\begin{array}{c}(2) \\
\text { Basic }\end{array}$ & $\begin{array}{l}(3) \\
\text { Help }\end{array}$ & $\begin{array}{l}\text { (4) } \\
\text { Play }\end{array}$ & $\begin{array}{l}(5) \\
\text { Talk }\end{array}$ & $\begin{array}{c}(6) \\
\text { Manage }\end{array}$ & $\begin{array}{c}(7) \\
\text { Read }\end{array}$ \\
\hline \multicolumn{8}{|c|}{ Weekdays } \\
\hline University degree $^{a}$ & $\begin{array}{l}6.74 \\
(2.30)\end{array}$ & $\begin{array}{l}5.33^{. * 3} \\
(1.37)\end{array}$ & $\begin{array}{c}0.45 \\
(0.62)\end{array}$ & $\begin{array}{l}-0.35 \\
(1.12)\end{array}$ & $\begin{array}{c}0.20 \\
(0.39)\end{array}$ & $\begin{array}{c}0.06 \\
(0.75)\end{array}$ & $\begin{array}{c}0.78 \\
(0.41)\end{array}$ \\
\hline Age & $\begin{array}{l}-0.08 \\
(0.19)\end{array}$ & $\begin{array}{l}-0.21^{*} \\
(0.10)\end{array}$ & $\begin{array}{c}0.08^{*} \\
(0.04)\end{array}$ & $\begin{array}{l}-0.10 \\
(0.08)\end{array}$ & $\begin{array}{l}0.07^{*} \\
(0.03)\end{array}$ & $\begin{array}{c}0.03 \\
(0.07)\end{array}$ & $\begin{array}{c}0.01 \\
(0.02)\end{array}$ \\
\hline Single ${ }^{b}$ & $\begin{array}{l}17.56^{*} \\
(8.66)\end{array}$ & $\begin{array}{c}8.89 \\
(5.31)\end{array}$ & $\begin{array}{l}7.10^{* *} \\
(2.52)\end{array}$ & $\begin{array}{c}1.80 \\
(4.15)\end{array}$ & $\begin{array}{l}-0.28 \\
(0.77)\end{array}$ & $\begin{array}{l}-0.10 \\
(1.23)\end{array}$ & $\begin{array}{c}-0.20 \\
(0.59)\end{array}$ \\
\hline Children in household & $\begin{array}{l}-2.63^{*} \\
(1.12)\end{array}$ & $\begin{array}{c}0.39 \\
(0.72)\end{array}$ & $\begin{array}{c}0.25 \\
(0.29)\end{array}$ & $\begin{array}{c}-3.70 \\
(0.53)\end{array}$ & $\begin{array}{c}0.35 \\
(0.19)\end{array}$ & $\begin{array}{c}0.36 \\
(0.41)\end{array}$ & $\begin{array}{l}-0.07 \\
(0.15)\end{array}$ \\
\hline Youngest child $3-5^{\mathrm{C}}$ & $\begin{array}{c}-30.31 \\
(3.45)\end{array}$ & $\begin{array}{c}-18.21 \\
(2.03)\end{array}$ & $\begin{array}{l}-0.19 \\
(0.48)\end{array}$ & $\begin{array}{c}-13.24 \\
(1.95)\end{array}$ & $\begin{array}{c}0.39 \\
(0.35)\end{array}$ & $\begin{array}{c}0.79 \\
(0.82)\end{array}$ & $\begin{array}{c}0.36 \\
(0.47)\end{array}$ \\
\hline Youngest child $6-9^{c}$ & $\begin{array}{c}-41.54 \\
(3.42)\end{array}$ & $\begin{array}{c}-24.14 \\
(2.07)\end{array}$ & $\begin{array}{l}2.36 \\
(0.63)\end{array}$ & $\begin{array}{c}-20.05^{* * *} \\
(1.78)\end{array}$ & $\begin{array}{l}1.03^{*} \\
(0.42)\end{array}$ & $\begin{array}{c}0.76 \\
(0.93)\end{array}$ & $\begin{array}{c}-1.36 \\
(0.42)\end{array}$ \\
\hline Youngest child $10-12^{c}$ & $\begin{array}{c}-56.93^{* * *} \\
(3.49)\end{array}$ & $\begin{array}{c}-30.98 \\
(2.07)\end{array}$ & $\begin{array}{c}1.40 \\
(0.74)\end{array}$ & $\begin{array}{c}-24.26 \\
(1.81)\end{array}$ & $\begin{array}{c}0.55 \\
(0.46)\end{array}$ & $\begin{array}{l}-1.09 \\
(0.93)\end{array}$ & $\begin{array}{c}-5.91^{* *} \\
(0.65)\end{array}$ \\
\hline East Germany ${ }^{d}$ & $\begin{array}{c}-56.93^{* * *} \\
(3.49)\end{array}$ & $\begin{array}{c}-30.98 \\
(2.07)\end{array}$ & $\begin{array}{c}1.40 \\
(0.74)\end{array}$ & $\begin{array}{c}-24.26 \\
(1.81)\end{array}$ & $\begin{array}{c}0.55 \\
(0.46)\end{array}$ & $\begin{array}{l}-1.09 \\
(0.93)\end{array}$ & $\begin{array}{c}-2.19 \\
(0.40)\end{array}$ \\
\hline Survey year $2012 / 2013^{e}$ & $\begin{array}{l}7.54 \\
(2.25)\end{array}$ & $\begin{array}{l}5.66^{*+*} \\
(1.27)\end{array}$ & $\begin{array}{c}0.54 \\
(0.55)\end{array}$ & $\begin{array}{c}1.46 \\
(1.20)\end{array}$ & $\begin{array}{c}-0.42 \\
(0.33)\end{array}$ & $\begin{array}{c}0.52 \\
(0.61)\end{array}$ & $\begin{array}{l}-0.30 \\
(0.24)\end{array}$ \\
\hline Uni \# 2012/2013 & $\begin{array}{l}-2.06 \\
(3.90)\end{array}$ & $\begin{array}{l}-3.35 \\
(2.20)\end{array}$ & $\begin{array}{l}-0.52 \\
(1.10)\end{array}$ & $\begin{array}{l}-1.27 \\
(1.88)\end{array}$ & $\begin{array}{c}0.61 \\
(0.61)\end{array}$ & $\begin{array}{c}2.27 \\
(1.30)\end{array}$ & $\begin{array}{c}0.64 \\
(0.57)\end{array}$ \\
\hline Constant & $\begin{array}{c}74.69^{* * *} \\
(7.67) \\
\end{array}$ & $\begin{array}{c}39.25 \\
(4.03) \\
\end{array}$ & $\begin{array}{l}-2.47 \\
(1.38) \\
\end{array}$ & $\begin{array}{c}37.91^{+*} \\
(3.54) \\
\end{array}$ & $\begin{array}{l}-2.07 \\
(1.07) \\
\end{array}$ & $\begin{array}{c}0.57 \\
(2.50) \\
\end{array}$ & $\begin{array}{c}1.75 \\
(0.93) \\
\end{array}$ \\
\hline Respondents & 2262 & 2262 & 2262 & 2262 & 2262 & 2262 & 2262 \\
\hline Observations & 4395 & 4395 & 4395 & 4395 & 4395 & 4395 & 4395 \\
\hline$\underline{\mathrm{R} \text {-squared }}$ & 0.157 & 0.174 & 0.015 & 0.117 & 0.011 & 0.006 & 0.030 \\
\hline \multicolumn{8}{|c|}{ Weekends } \\
\hline University degree $^{a}$ & $\begin{array}{c}12.92 \\
(3.65)\end{array}$ & $\begin{array}{l}5.09^{*} \\
(1.75)\end{array}$ & $\begin{array}{c}1.02 \\
(0.72)\end{array}$ & $\begin{array}{l}5.52^{*} \\
(2.66)\end{array}$ & $\begin{array}{c}0.33 \\
(0.60)\end{array}$ & $\begin{array}{l}-0.33 \\
(1.03)\end{array}$ & $\begin{array}{l}1.30^{*} \\
(0.48)\end{array}$ \\
\hline Age & $\begin{array}{l}-0.42 \\
(0.25)\end{array}$ & $\begin{array}{l}-0.26^{*} \\
(0.13)\end{array}$ & $\begin{array}{c}0.02 \\
(0.04)\end{array}$ & $\begin{array}{l}-0.15 \\
(0.17)\end{array}$ & $\begin{array}{c}0.07 \\
(0.05)\end{array}$ & $\begin{array}{l}-0.09 \\
(0.06)\end{array}$ & $\begin{array}{l}-0.01 \\
(0.03)\end{array}$ \\
\hline Single ${ }^{b}$ & $\begin{array}{c}13.73 \\
(12.69)\end{array}$ & $\begin{array}{c}3.72 \\
(3.84)\end{array}$ & $\begin{array}{l}-1.80^{*} \\
(0.74)\end{array}$ & $\begin{array}{c}8.53 \\
(11.10)\end{array}$ & $\begin{array}{c}0.82 \\
(2.38)\end{array}$ & $\begin{array}{c}1.43 \\
(4.30)\end{array}$ & $\begin{array}{c}1.46 \\
(2.18)\end{array}$ \\
\hline Children in household & $\begin{array}{l}-4.87^{*} \\
(1.67)\end{array}$ & $\begin{array}{l}-0.56 \\
(0.85)\end{array}$ & $\begin{array}{c}0.32 \\
(0.33)\end{array}$ & $\begin{array}{c}-5.32 \\
(1.14)\end{array}$ & $\begin{array}{l}-0.20 \\
(0.23)\end{array}$ & $\begin{array}{c}1.30^{*} \\
(0.60)\end{array}$ & $\begin{array}{l}-0.33 \\
(0.18)\end{array}$ \\
\hline Youngest child $3-5^{\mathrm{C}}$ & $\begin{array}{c}-42.59^{* * *} \\
(5.22)\end{array}$ & $\begin{array}{c}-23.81 \\
(2.77)\end{array}$ & $\begin{array}{l}-0.13 \\
(0.41)\end{array}$ & $\begin{array}{c}-21.29^{* * * *} \\
(3.79)\end{array}$ & $\begin{array}{c}0.71 \\
(0.71)\end{array}$ & $\begin{array}{c}2.13 \\
(1.18)\end{array}$ & $\begin{array}{c}0.01 \\
(0.69)\end{array}$ \\
\hline Youngest child $6-9^{c}$ & $\begin{array}{c}-66.59^{* * *} \\
(5.02)\end{array}$ & $\begin{array}{c}-33.98 \\
(2.68)\end{array}$ & $\begin{array}{l}1.80^{* *} \\
(0.68)\end{array}$ & $\begin{array}{c}-38.77^{*+*} \\
(3.43)\end{array}$ & $\begin{array}{l}1.55^{*} \\
(0.78)\end{array}$ & $\begin{array}{l}4.42^{* *} \\
(1.48)\end{array}$ & $\begin{array}{c}-1.69^{* *} \\
(0.59)\end{array}$ \\
\hline Youngest child $10-12^{c}$ & $\begin{array}{c}-91.58 \\
(5.04)\end{array}$ & $\begin{array}{c}-42.41 \\
(2.64)\end{array}$ & $\begin{array}{l}1.80^{* *} \\
(0.63)\end{array}$ & $\begin{array}{c}-49.20^{*+*} \\
(3.53)\end{array}$ & $\begin{array}{c}-0.43 \\
(0.75)\end{array}$ & $\begin{array}{c}2.48 \\
(1.32)\end{array}$ & $\begin{array}{c}-2.85 \\
(0.57)\end{array}$ \\
\hline
\end{tabular}




\begin{tabular}{|c|c|c|c|c|c|c|c|}
\hline & $\begin{array}{c}(1) \\
\text { Total }\end{array}$ & $\begin{array}{c}(2) \\
\text { Basic }\end{array}$ & $\begin{array}{c}(3) \\
\text { Help }\end{array}$ & $\begin{array}{c}\text { (4) } \\
\text { Play }\end{array}$ & $\begin{array}{c}(5) \\
\text { Talk }\end{array}$ & $\begin{array}{c}(6) \\
\text { Manage }\end{array}$ & $\begin{array}{c}(7) \\
\text { Read }\end{array}$ \\
\hline East Germany $^{d}$ & $\begin{array}{l}-5.09 \\
(3.53)\end{array}$ & $\begin{array}{l}-1.39 \\
(1.75)\end{array}$ & $\begin{array}{l}-0.07 \\
(0.49)\end{array}$ & $\begin{array}{l}-1.53 \\
(2.45)\end{array}$ & $\begin{array}{c}0.52 \\
(0.72)\end{array}$ & $\begin{array}{l}-2.42^{* *} \\
(0.92)\end{array}$ & $\begin{array}{l}-0.49 \\
(0.40)\end{array}$ \\
\hline Survey year $2012 / 2013^{\mathrm{e}}$ & $\begin{array}{c}12.25^{\star \star \star} \\
(3.40)\end{array}$ & $\begin{array}{l}4.71^{* *} \\
(1.72)\end{array}$ & $\begin{array}{c}0.28 \\
(0.50)\end{array}$ & $\begin{array}{c}2.98 \\
(2.26)\end{array}$ & $\begin{array}{c}0.47 \\
(0.61)\end{array}$ & $\begin{array}{c}3.02^{*} \\
(1.23)\end{array}$ & $\begin{array}{c}0.24 \\
(0.33)\end{array}$ \\
\hline Uni \# 2012/2013 & $\begin{array}{c}3.13 \\
(6.19)\end{array}$ & $\begin{array}{l}-0.22 \\
(3.18)\end{array}$ & $\begin{array}{c}1.61 \\
(1.27)\end{array}$ & $\begin{array}{l}-2.40 \\
(4.00)\end{array}$ & $\begin{array}{c}0.16 \\
(1.17)\end{array}$ & $\begin{array}{c}2.57 \\
(2.32)\end{array}$ & $\begin{array}{c}0.30 \\
(0.85)\end{array}$ \\
\hline Constant & $\begin{array}{c}126.28^{* \star *} \\
(9.87)\end{array}$ & $\begin{array}{c}54.82^{\star \star \star} \\
(5.17)\end{array}$ & $\begin{array}{l}-1.15 \\
(1.17) \\
\end{array}$ & $\begin{array}{c}68.33^{* \star *} \\
(6.99)\end{array}$ & $\begin{array}{l}-0.97 \\
(1.75) \\
\end{array}$ & $\begin{array}{c}1.13 \\
(2.50) \\
\end{array}$ & $\begin{array}{l}3.41^{\star \star \star} \\
(0.93)\end{array}$ \\
\hline Respondents & 2270 & 2270 & 2270 & 2270 & 2270 & 2270 & 2270 \\
\hline Observations & 2439 & 2439 & 2439 & 2439 & 2439 & 2439 & 2439 \\
\hline R-squared & 0.226 & 0.201 & 0.015 & 0.159 & 0.007 & 0.012 & 0.032 \\
\hline
\end{tabular}

